\title{
Publisher Correction: Global ocean heat content in the Last Interglacial
}

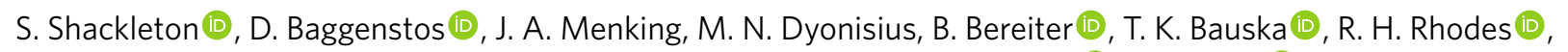
E. J. Brook, V. V. Petrenko, J. R. McConnell, T. Kellerhals, M. Häberli, J. Schmitt (D), H. Fischer (D) and J. P. Severinghaus

Correction to: Nature Geoscience https://doi.org/10.1038/s41561-019-0498-0, published online 6 January 2020.

In the version of this Article originally published, references 41-51 were in the wrong order in the reference list. These references should have appeared as below. In addition, in Methods, in the sentence beginning 'We accounted for the effects of changes' the text 'Toggweiler et al. ${ }^{34}$ corrected for isostatic effects' should have read 'Grant et al. ${ }^{45}$ corrected for isostatic effects'. This has now been corrected.

41. Elderfield, $\mathrm{H}$. et al. Evolution of ocean temperature and ice volume through the mid-Pleistocene climate transition. Science 337, 704-709 (2012).

42. Lisiecki, L. E. \& Raymo, M. E. A Pliocene-Pleistocene stack of 57 globally distributed benthic $\delta^{18} \mathrm{O}$ records. Paleoceanography 20, PA1003 (2005).

43. Schneider, R., Schmitt, J., Köhler, P., Joos, F. \& Fischer, H. A reconstruction of atmospheric carbon dioxide and its stable carbon isotopic composition from the penultimate glacial maximum to the last glacial inception. Clim. Past 9, 2507-2523 (2013).

44. Wang, Y. et al. Millennial- and orbital-scale changes in the East Asian monsoon over the past 224,000 years. Nature 451, 1090-1093 (2008).

45. Grant, K. M. et al. Sea-level variability over five glacial cycles. Nat. Commun. 5, 5076 (2014).

46. Marcott, S. A. et al. Centennial-scale changes in the global carbon cycle during the last deglaciation. Nature 514, 616-619 (2014).

47. Buizert, C. et al. Precise interpolar phasing of abrupt climate change during the last ice age. Nature 520, 661-665 (2015).

48. Buizert, C. et al. The WAIS-Divide deep ice core WD2014 chronology - part 1: methane synchronization (68-31 ka bp) and the gas age-ice age difference. Clim. Past 11, 153 (2015).

49. Dykoski, C. A. et al. A high-resolution, absolute-dated Holocene and deglacial Asian monsoon record from Dongge Cave, China. Earth Planet. Sci. Lett. 233, 71-86 (2005).

50. Wang, Y. et al. A high-resolution absolute-dated Late Pleistocene monsoon record from Hulu Cave, China. Science 294, 2345-2348 (2001).

51. Roberts, N. L., Piotrowski, A. M., McManus, J. F. \& Keigwin, L. D. Synchronous deglacial overturning and water mass source changes. Science 327, 75-78 (2010).

Published online: 7 February 2020

https://doi.org/10.1038/s41561-020-0543-z

This is a U.S. government work and not under copyright protection in the U.S.; foreign copyright protection may apply 2020 